\title{
Empirical Descriptions of Criminal Sentencing Decision-Making
}

\section{The use of statistical causal modelling}

\author{
RASMUS H. WANDALL ${ }^{*}$
}

\section{$1 \quad$ Introduction}

There is nothing new about using empirical social science in the realm of sentencing law and practice. Sentencing has employed empirical descriptions of crime and sanctioning for centuries, just as law, crime, and punishment have been the subjects of sociological analysis throughout modern time. The novelty - if any - lies in the volume and authority of empirical social scientific descriptions over the last half-century. Today, empirical social science is an indispensable part of administrating sentencing systems in the Scandinavian countries. Many sentencing policies are prepared with reference to empirical accounts of sentencing practices and problems. Empirical descriptions of legal decision-making processes are more frequent, and empirical surveys of public and user attitudes towards sentencing decision-making, its quality and efficiency, have become integral parts of organisational management in local, regional, and national jurisdictions.

Empirical social science is used in many different ways with regards to sentencing. First, it is used to explain the causes, interpretive frameworks, as well as the consequences of sentencing law and practice. ${ }^{1}$ What are the causes and the effects of the use of mediation and other alternatives? What is the explanation of the changing regulatory techniques employed in sentencing law? Are they reactions to a transnational deficit in public confidence? What are the effects of specific sentencing arrangements on specific crime preventive goals? For example, the correctional value of prison and suspended sentences,

Senior Research Fellow, Faculty of Law, University of Bergen

Aubert, Om Straffens sosiale funsjon (Akademisk Forlag 1954), Lappi-Seppälä, Explaining Imprisonment in Europe, European Journal of Criminology 8, no. 4 (2011), Aas, Sentencing in the Age of Information. From Faust to Macintosh (GlassHouse Press 2005). 
of community service or youth sanctions? ${ }^{2}$ Second, empirical social science is increasingly used as a theoretical and methodological framework to compare sentencing and other legal disciplines across countries. ${ }^{3}$ For example, by exploring if sentencing arrangements in Scandinavia are exceptions to otherwise widespread Western penal trends. ${ }^{4}$ Also, with social science comes a greater appreciation of the forms and techniques of transnational structures and how they interplay with local ones, leaving sentencing law and practice shaped by both. ${ }^{5}$

In this article, I investigate the most frequently used model in social scientific descriptions of sentencing decision-making - the statistical causal model. After having described the model and its characteristics, I identify and discuss three different aspects of sentencing decision-making that significantly challenge the usefulness of this model. My claim is that the model suffers from significant shortcomings. The model has a poor conception of law, it fails to grasp the dynamic processes through which facts and law are constructed, and it does not adapt to the rapidly changing organisational landscape of sentencing decision-making. Other and new models and methodologies should be brought to use.

\section{The statistical causal model of sentencing decision-making}

The primary function of most empirical descriptions of sentencing is to provide a reliable mirror in which sentencing law and policy can look to see if it recognises itself, if it likes what it sees, and if other and non-legal structures bear upon sentencing decision-making. Is offence severity actually the most important sentencing determinant? Does ethnicity matter to the sentencing? Which sentencing ideologies actually drive judges? And

2 Examples of this kind of Scandinavian research include Bondeson, Fangen i fångsamhället. Socialisationsprocesser vid ungdomsvårdsskola, ungdomsfängelse, fängelse och internering (Norstedt 1974), Clausen, Samfundstjeneste - virker det? (Djøfs Forlag 2007), Kjær, The Effects of Mixing Offenders with Non-Offenders: Findings from a Danish Quasi Experiment, Journal of Scandinavian Studies in Criminology and Crime Prevention 12, no. 1 (2011), Tranæs and Geerdsen, Forbryderen og samfundet. Livsvilkår og uformel straf (Gyldendal 2008). Examples are also found in Kyvsgaard, Hvad virker - hvad virker ikke? (Djøfs Forlag 2006).

3 See Cotterell, Comparatists and Sociology, in Comparative Legal Studies: Traditions and Transitions, eds. Legrand and Munday (Cambridge University Press 2003), Friedman, The Concept of Legal Culture, in Comparing Legal Cultures, ed. Nelken (Aldershot 1997), Nelken, ed., Comparative Criminal Justice and Globalization (Ashgate Publishing 2011). Concrete examples include Jones and Newburn, Comparative Criminal Justice Policy-Making in the United States and the United Kingdom. The Case of Private Prisons, British Journal of Criminology 45 (2005), Three Strikes and You're Out. Exploring Symbol and Substance in American and British Crime Control Politics, British Journal of Criminology 46 (2006).

4 Lappi-Seppälä 2011, Pratt, Scandinavian Exceptionalism in an Era of Penal Excess: Part I: The Nature and Roots of Scandinavian Exceptionalism, British Journal of Criminology 48, no. 3 (2008). See also Ugelvik and Dullum, Penal Exceptionalism? Nordic Prison Policy and Practice (Routledge 2012).

$5 \quad$ Nelken, ed., 2011. 
what effect, if any, do confessions have on the length of prison sentences? Is sentencing practice uniform between courts?

Answers to these and other empirical questions of sentencing law and practice have become an accepted part of some legal research and of much policy-making. Methodologically, there are significant variations. Some studies use ethnographic approaches relying on qualitative and interpretative methods. Others, and by far the overwhelming majority of studies, continue to rely on quantitative and statistical methods designating sentencing decision-making as a causal relationship between fixed sentencing factors and sentencing outcomes. Through a variety of shapes and levels of complexity, the model plays the by far biggest descriptive role in sentencing research and policy. ${ }^{6}$

The simple version - counting the type, number, and amount of sanctions for particular offences - is well known and has been practiced for more than a century. It continues to dominate empirical work in public policy making. In the last thirty to forty years, statistical descriptions have become more common in both research and in policy, more reliable, and much more detailed. With the advancement of practical statistical tools in the 1960s, 70s, and 80s, and with the increased power of computers from the 80s onwards, multivariate statistical analysis (examining the relationship between multiple sentencing factors and the sentencing outcome) have become more mainstream to use. ${ }^{7}$ It is this advancement of practical statistical technologies that has made available current empirical descriptions of sentencing decision-making and the factors that determine its outcome.

There is no question that the technical and methodological development from the empirical studies of von Eyben and Aubert in the 1950s and 60s to the later studies of Vestergaard in the 1980s, and again to the more recent studies of Kyvsgaard, BRA, Wandall and Hinkkanen and Lappi-Seppälä in the 1990s and 2000s, is significant. ${ }^{8}$ Yet, the basic structure remains the same: A model of sentencing that measures the variation in sentencing outcome (type of sanction and size of sanction) as a function of variations in multiple sentencing factors. In the following I will refer to this model as 'the statistical causal model' or just 'the model'.

6 See for example the overview of Scandinavian sentencing research in Hinkkanen and Lappi-Seppälä, Sentencing Theory, Policy, and Research in the Nordic Countries, Crime and Justice 40, no. 1 (2011).

7 Hacking, The Taming of Chance (Cambridge University Press 1990), Stigler, Statistics on the Table. The History of Statistical Concepts and Methods (Harvard University Press 2000).

$8 \quad$ Aubert, Krigsrettsdommene i militærnektersaker, Tidsskrift for Rettsvitenskap 69 (1956) and Straff og lagdeling (University of Oslo 1963), BRÅ, Sannolikheten att dömas till fängelse. En Statistisk analys (Brottsförebyggande Rådet 2000), von Eyben, Strafudmåling (Gads Forlag 1950), Hinkkanen and Lappi-Seppälä 2011, Kyvsgaard, Samfundstjeneste i empirisk belysning, Juristen 4 (1999), Vestergaard, Sanktionsundersøgelsen. Design og heuristik (University of Copenhagen 1982), Wandall 2004. 


\section{The design of the model}

Hogarth aptly describes this model of sentencing-decision making as a black box through which selected sentencing factors affect the outcome of sentencing decision-making. ${ }^{9}$ What happens inside the black box is not clear. In some such models a few selected procedural factors are included to account for some of the processes between input and output factors. Models almost never account for the effect of variations between different kinds of sentencing institutions (court, prosecution, police), and almost never for the effect of variations between different courts or judges. ${ }^{10}$

The typical trademark of the model is its pragmatic combination of quantitative methodology and causal logic. It uses quantitative methodology to study the correlations between semantically pre-defined sentencing factors and pre-defined sentencing outcomes; and it relies on a logic of causality by assuming that statistical correlations between sentencing factors and outcome factors are causally related, when controlling for other possible correlations. For example, a categorically defined factor for 'prior criminal record' and its correlation with 'length of imprisonment, measured in months. ${ }^{11}$

\section{Sentencing factors}

In describing sentencing decision-making this statistical causal model typically includes sentencing factors (variables) for the severity of crime, the prior criminal record, the personal circumstances of the defendant, and a few procedural circumstances, such as trial form and confession. Sometimes interaction effects between some variables are included in the analysis.

The criminal offence is always included and with few exceptions follows officially recognised distinctions, e.g. value of stolen property, aggravated nature of violence, or the weight of illegal drugs. Though we do know that the effect of offences vary according to a range of different internal narratives, this is typically not reflected in the variables. ${ }^{12}$ Hinkkanen and Lappi-Sepälä include a wide range of offence characteristics, extracted from written judgments. Yet, even that source is limited to what has actually been written down in official court documents, and is often not identical to all that was communicated during trial.

The prior criminal record is typically constructed as a dichotomous variable (prior crime; no prior crime). In some studies, a second distinction between prior similar and prior different crime, is included. However, rarely, if ever, are other distinctions included.

$9 \quad$ Hogarth, Sentencing as a Human Process (University of Toronto Press 1971).

10 See further references in Wandall 2004 p. 155. See also Grendstad, Shaffer, and Waltenburg, Ideologi og grunnholdninger hos dommerne i Norges Høyesterett, Lov og Rett 51, no. 4 (2012).

11 See for example Hinkkanen and Lappi-Seppälä 2011 p. 396.

12 Ibid. 
The same goes for the difference in the effect that prior crime can be expected to have for different offence categories. ${ }^{13}$

Personal and social circumstances of the defendant are often included in statistical causal models of sentencing. Age is typically included as a dichotomous variable $(+/-18$ years of age). This does mirror the official discourse, but does not reflect the fact that statistical effects are found between different age groups too, or with the fact that the effect of age can be expected to vary with the effect of other variables (offence category, prior crime, gender). Other aspects of personal and social circumstances - income, education, family conditions, employment, social ties, etc. are more difficult to collect data on for practical methodological reasons. In models used in policy reports, such variables are almost never included. In research projects, attempts are more often made to capture useful indicators for such variables. BRÅ used an aggregate statistical construction of presence of mitigating circumstances. ${ }^{14}$ Kyvsgaard used available information about defendant's 'suitability for community service', and Wandall used a range of indicators of social integration. ${ }^{15}$ Gender is included as a suspect category more and more often, as is ethnicity where numbers allow. ${ }^{16}$

Fourth, procedural factors are increasingly included in empirical descriptions and modelling of sentencing decision-making. Trial form, confession, and length of trial are among the more often included. However, well-known interaction effects between offence-related variables and procedural variables are rarely included as are other and equally empirically relevant procedural factors. Among others, the latter includes partly withdrawal of charges, part confessions, and the use of pre-trial custody. ${ }^{17}$

When it comes to the sentencing outcome, statistical causal models typically include the sanctions formally recognised as penal sanctions (conditioned charge withdrawal, fine, suspended sentences, combination sanctions, prison sanctions, etc.). Less often are procedural decisions and ancillary orders (e.g. confiscation, commercial disqualification, and other administrative orders), as well as monetary damages, included.

Statistical causal models bring enormous power to the description, analysis, and understanding of sentencing practices. Undoubtedly, they serve as an important tool in maintaining Scandinavian sentencing law and policy in an on-going dialogue with actual practices. Perhaps therefore it seems only natural to take a closer look at the design of this model and how it fares with empirical and theoretical challenges in the realm of sentenc-

\footnotetext{
13 Aubert 1963, Wandall 2004.

14 BRÅ 2000.

$15 \quad$ Kyvsgaard 1999, Wandall 2004.

16 Holmberg and Kyvsgaard, Are Immigrants and Their Descendants Discriminated against in the Danish Criminal Justice System?, Journal of Scandinavian Studies in Criminology and Crime Prevention 4, no. 2 (2003).

$17 \quad$ Vestergaard 1982, Wandall 2004.
} 
ing. In the following I will focus on three empirical and theoretical challenges and discuss to what extent the statistical causal model is capable of responding to these.

\section{The legal complexity of sentencing}

The first challenge is about how the statistical causal model describes law and legal structures. Understanding how - not merely if - law matters in criminal sentencing has become increasingly relevant. The number of qualitatively different statutory rules, official guidelines, managerial standards, court practice guidance, and other kinds of regulations are being produced in an unprecedented volume. The institutions involved in the production of legal rules and standards are no longer merely legislature and courts, but also the police, the prosecution service, the department of correction and the many specialised departments that handle the wide range of different categories of cases. Any empirical ambition to describe sentencing and the structures that govern it requires a conception of law and legal structures that reflects this complexity.

The assumption of the statistical causal model is that it is possible to describe legal factors using social scientific variables, and that we can distinguish between legal and extra-legal factors using empirical social science validity tests of statistical relationships. Hinkkanen and Lappi-Sepälä defend research based on this assumption in their account of Scandinavian sentencing:

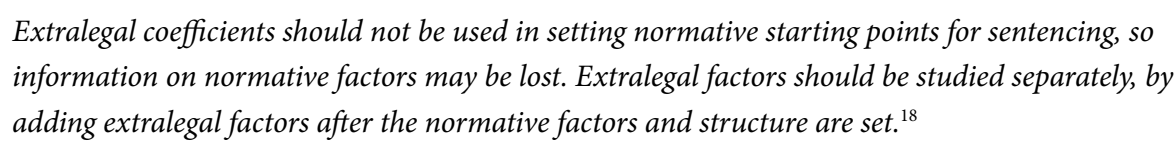

However intuitively straightforward this sounds, it is problematic. First of all, describing legal factors using social scientific categories involves a change in disciplinary discourse. We rarely take notice of these disciplinary changes - but we do make them. Max Weber, who famously associated legal norms with social control, wrote about this:

When we speak of 'law', 'legal order', or 'legal proposition', close attention must be paid to the distinction between the legal and the sociological points of view.

the ideal 'legal order' of legal theory has nothing directly to do with the world of real economic conduct, since both exist on different levels. One exists in the realm of the 'ought' while the other deals with the world of the 'is'. If it is nevertheless said that the economic and the legal order are intimately related to one another, the latter is understood, not in the legal, but in the sociological sense, i.e., as being empirically valid. ${ }^{19}$

$18 \quad$ Hinkkanen and Lappi-Seppälä 2011 p. 311.

19 Weber, Economy and Society (University of California Press 1978), p. 311-312. 
However different from any contemporary theoretical position, Weber's remark serves well to remind us that empirical social scientific descriptions are exactly that - social scientific and empirical. It is in this latter sense that statistical causal models describe sentencing decision-making. This means that the model uses a different test of validity to determine if a sentencing factor is relevant or not, than do law. In the statistical causal model the test is if there is a statistically probable correlation of relevance. In a traditional legal model the question is rather if there is a sufficient legal reference. The validity tests are different and one cannot deduce from one to the other. Think for example of the fact that while empirical studies have found that socio-economic marginalised groups of young men are targeted discriminatorily in sentencing, all the legal decisions that went into these empirical descriptions were typically upheld in court and when appealed, also on appeal.

The second way in which this difference in disciplinary point of view is relevant, is that legal concepts do not have fixed meanings which can be translated into social scientific statistical categories. When translated, an irreversible change or selection of meaning also takes place. This cannot be handled by a mere distinction between legal and extra-legal factors. A legal category of 'confession', 'risk', 'suitable for community service,' 'youth' may be carriers of a variety of different meanings into the sentencing process. When translated into statistical categories, these meanings are lost. This socio-legal reality is well described in the Danish police as well as in Danish courts. ${ }^{20} \mathrm{I}$ will return to this below.

Rather than seeing the statistical causal model as a tool to determine the relevance of legal and extra-legal factors, we should see the model as an irreversible translation of law into empirical social science. Despite its claim, the model cannot conclude anything about the law or legal structure of sentencing, but only about its social practice. And it cannot contribute to a better understanding of how law matters and how different regulatory techniques matter.

There are several theoretical developments that can help to better understand the connection between a social scientific description and law or legality. The strongest ones include the theory of structuration by Giddens (see for example the work of Henham), the theory of autopietic systems theory and its variations by Luhmann and Teubner (see for example the work of Aviram and of Wandall), and the reflexive matrix of sociology of

$20 \quad$ Holmberg, Politiets skøn i retssociologisk belysning (University of Copenhagen: 1999) and Policing Stereotypes. A Qualitative Study of Police Work in Denmark (Galda+Wilch Verlag 2003), Wandall 2004 and Decisions to Imprison. Court Decision-Making Inside and Outside the Law, book series: Advances in Criminology (Ashgate Publishing 2009). 
law by Banakar. ${ }^{21}$ It is only the aim here to mention their presence, not to discuss them. They are markedly different from one another, but do share an ability to understand - in different ways - the difference in discourse between a legal and a social scientific point of view and frame it in a theoretical approach. This involves accepting variable meaning structures in the process of legal decision-making in sentencing. Accordingly, sentencing is not only a matter of which factor or norm (offence severity, offender characteristics, confession, etc.), but also of what meanings these different norms and facts carry into the sentencing.

The meanings of 'severity', 'confession', of 'mitigating circumstances', or 'dangerous offender', may vary in decision-making while the norm remains the same. Every legal rule and every legal fact acquires its operational meaning in a given context and therefore varies. In the case of sentencing decision-making, meanings are constructed through the institutions and people who prepare the case, the prosecution, the court, in the dynamics of the courtroom, and the ethics of the local community. Descriptions of offence severity and personal circumstances are not given facts but are constructed in the process of investigation, prosecution, and court decision-making in the framework of a particular political, social and cultural context. ${ }^{22}$ That is what provides a sufficient fluidity for empirical social scientific descriptions to tell one story about sentencing decision-making and the legal framework to uphold a different one. On this level of meaning structures there is an operation of sentencing that is invisible to the law, yet constitutive of how norms of legal sentencing decision-making operate. This is a perspective that allows us a more complex but also more reliable description of how law matters in sentencing without simplifying law to a static norm and without denying law its normative character.

\section{Sentencing as a process of constructing facts and law}

The second challenge of the statistical causal model is that facts and law in sentencing decision-making are themselves products of the social constructions and institutional dynamics in the decision-making processes of the justice system. There is a longer and

${ }_{21} \quad$ Aviram, Managing Disobedience as Crime: Legal and Extra-Legal Discourse in Addressing Unauthorized Absences and Conscientious Objection to Military Service in Israel (University of California at Berkeley 2005), Banakar, Merging Law and Sociology. Beyond the Dichotomies in Socio-Legal Research (Galda+Wilch Verlag 2002), Giddens, The Constitution of Society. Outline of a Theory of Structuration (Polity Press 1984), Henham, Human Rights, Due Process, and Sentencing, British Journal of Criminology 38 (1998) and Problems of Theorizing Sentencing Research, International Journal of Sociology of Law 28 (2000), Luhmann, Das Recht Der Gesellschaft ( Suhrkamp 1993), Teubner, Law as an Autopoietic System ( Blackwell 1993), Wandall 2009.

22 Johansen, Livshistorier i straffesagen. Vidensprocesser om sigtedes person (University of Copenhagen 2012), Wandall, Resisting Risk Assessment? Pre-Sentence Reports and Individualized Sentencing in Denmark, Punishment and Society. The International Journal of Penology 12, no. 3 (2010). 
established tradition for this wider approach to study court decision-making. ${ }^{23}$ This particular approach shows that the legal rules and the facts that structure sentencing decision-making do not (only) derive their meanings from the law itself or from the facts as they are brought into the decision-making process, but (also) from the institutional, procedural and social context and dynamics of the legal decision-making. This is a complexity that the statistical causal model of sentencing decision-making cannot handle, but nevertheless a complexity that is unavoidable. There does exist a handful of such studies in Scandinavia, but the number remains small, and we continue to have limited knowledge of this aspect of sentencing decision-making. ${ }^{24}$ In the following I will look at one recent major contribution to illustrate.

Johansen's 'Livshistorier i straffesagen'

Johansen studied the processes of constructing information about the individual offender in the criminal process. ${ }^{25}$ The title of the study is 'Life stories in the criminal case. Knowledge processes about the defendant's person. ${ }^{26}$ Johansen uses the actor-network theory of Bruno Latour to show that facts about the individual offender are not merely established in the process as objective legal facts, but are integral parts of the networks of relations that exist between people, institutions, and knowledge in the decision-making processes leading to criminal sentencing. ${ }^{27}$ There are several social constructivist approaches to this insight. Latour represents one of the most promising. According to his theory information gets translated and negotiated through the individual stages of the decision-making process and their internal and external dynamics. Facts are themselves resources of the internal dynamics and as such are also carriers of purposes in the pro-

23 See for example Bennet and Feldman, Reconstructing Reality in the Courtroom. Justice and Judgement in American Culture (Rutgers University Press 1984), Latour, The Making of Law: An Ethnography of the Conseil D'etat (Polity Press 2010), McBarnet, Conviction: Law, the State and the Construction of Justice (MacMillan 1981), Nelken, The Limits of the Legal Process. A Study of Landlords, Law, and Crime (Academic Press 1983), Rosen, The Anthropology of Justice. Law as Culture in Islamic Society (Cambridge University Press 1984) and The Justice of Islam (Oxford University Press 2000), Scheffer, Hannken-Illjes, and Kozin, Criminal Defence and Procedure. Comparative Ethnographies in the United Kingdom, Germany, and the United States (Palgrave MacMillan 2010).

24 Examples of related research in Scandinavia include Andenæs, ed., Kommunikasjon og rettssikkerhet. Utlendingers og språklige minoriteters møte med politi og domstoler (Unipub 2000), Diesen, Lernestedt, and Lindholm, Liket inför lagen (Natur och Kultur 2005), Hald, Web without a Weaver: On the Becoming of Knowledge. A Study of Criminal Investigation in the Danish Police (Aarhus University 2010), Jakobsen, Legitimitetens logik, institutionelle dilemmaer i det sociale klagesystem (University of Copenhagen 2004), Johansen 2012, Johansen and Stæhr, Lige for loven: En pilotundersøgelse af behandlingen af etniske minoriteter i straffesager (ICJ: 2007), Järvinen and Mik-Meyer, Indledning: at skabe en klient, in At skabe en klient: institutionelle identiteter i socialt arbejde, eds. Järvinen and Mik-Meyer (Hans Reitzels Forlag 2003), Kjus, Sakens fakta: fortellingsstrategier i straffesaker (Unipub, 2008), Wandall 2010.

25 Johansen 2012.

26 My translation. Title in Danish: 'Livshistorier i straffesagen. Vidensprocesser om sigtedes person'.

$27 \quad$ Latour 2010. 
cess. The result is that sentencing decision-making cannot be understood in isolation from the agents and institutions involved in the processing of cases; most importantly the Department of Corrections, the police, the prosecution and the courts. In her empirical findings, Johansen shows how facts about the individual offender are constructed around different meanings of normality, integration, and suitability. In turn, these meanings are typically framed in a spectrum between the majority and minorities, between 'us' and 'them', and are tied to particular ways of looking at the relationship between the individual and society. Johansen describes how social and cultural distinctions take on central roles in defining these meaning-structures. For example, 'risk' is not just an evaluation of future crime, but also an evaluation of how normal the defendant is, as understood in the settings of the Danish networks and institutions under study. Johansen even shows how silence (cultural silence) allows meanings of cultural differences to enter the process of decision-making meaningfully.

What this and similar studies show is that law and fact, as meaningfully constructed in the process of sentencing, are tied to the dynamics of the processing, its actors and their interaction, and to the organisational, social and cultural context of the decision-making process. It is this fluidity of meanings of fact and law that the statistical causal model misses. In effect, the model can only represent one of many constructions of sentencing decision-making, leaving other ones undescribed. For example, an offender is not merely young or adult $(+/-18)$, but is within reach or not, morally immature or not, and there may be institutional interests in and cultural preferences for working with some youth and not others. Prior crime is not merely prior crime. It may convey different meanings for different offence categories and for different types of offenders, and it may be used for different strategic purposes during the criminal justice process.

Besides this general socio-legal consequence of this established insight, there are also specific Nordic consequences. Immigration has changed the cultural landscape and introduced a new uncertainty in the everyday practice of criminal sentencing. ${ }^{28}$ The cultural homogeneity, comparatively so characteristic for Scandinavian countries, has been replaced by a cultural heterogeneity - yet without the institutional languages to go with it. ${ }^{29}$ With this come the problems of language, shared meanings of facts and rules, as well as the procedural challenges of misunderstandings between the agents of the process. However, the more fundamental uncertainty is that cultural interpretations become part

$28 \quad$ Højsgaard Andersen and Tranæs, Etniske minoriteters overreprcesentation i strafferetlige domme (Syddansk Universitetsforlag 2011), Sarnecki, Strukturell diskriminering i rättsväsendet på grund av etnisk och religiös tillhörighet. En introduktion och sammenfattning, in Är rättvisan rättvis? Tio perspectiv på diskriminering av etniska och religiösa minoriteter inom rättssystemet, ed. Sarnecki, Utredningen om makt, integration och strukturell diskriminering (Statens Offenliga Utredningar 2006).

29. This description is not meant to disregard the already existing plurality of cultures in Norway, Sweden and Finland. However, comparatively speaking, and considering the culturally different immigration, which all Scandinavian countries have experienced in the last twenty years, it is clear that criminal justice institutions today have to deal with a culturally more heterogeneous group of people than before. 
of the process. All agents do not share a common meaning of a 'confession. ${ }^{30}$ That kind of uncertainty separates those who hold different understandings from each other, introducing social and cultural differences as operational distinctions in the decision-making process. The most likely effect is that it reinforces the difference in identity between cultural and social groups of society, fuelling a cycle of partial distrust in the law and its institutions from those groups of people. ${ }^{31}$ Again, the challenge is not so much to study if law governs, but how law governs the decision-making process to accommodate these different social and cultural meanings without distancing any of them. This brings us to the third and final social scientific perspective of sentencing decision-making that I want to address: the organisational framework of sentencing.

\section{The formal organisation of sentencing}

We know from decades of organisational research that courts in action, just like other legal and non-legal institutions, take on a nature of their own. ${ }^{32}$ The actual social practices of courts, prosecution offices, and police offices will always differ from their formal ideal to some extent. ${ }^{33}$ Following this line of insight brings two developments to our attention, both of which challenge the statistical causal model of sentencing decision-making.

First of all, while our legal scholarly focus continues to be the courts and in particularly the upper courts, sentencing is moving down and out into new organisational settings. More cases are handled in the lower courts and more cases are handled by administrative agencies. The public prosecution finishes more cases than ever before. The police is by far the most frequent authority to hand down fines, and other departments - anything from environmental offices to departments of animal safety or social security - are instrumental in the processing, conviction and sentencing of offenders. Moreover, correctional

30 Johansen and Stæhr 2007.

31 Jackson et al., Why Do People Comply with the Law? Legitimacy and the Influence of Legal Institutions, British Journal of Criminology 52, no. 6 (2012), Jackson and Sunshine, Public Confidence in Policing. A Neo-Durkheimian Perspective, British Journal of Criminology 47 (2007), Tyler and Huo, Trust in the Law. Encouraging Public Cooperation with the Police and Courts (Russel Sage Foundation 2002).

32 Merton, The Unanticipated Consequences of Purposive Social Action, American Sociological Review 1, no. 6 (1936), Selznick, Leadership in Administration (University of California Press 1984). In the sociology of law the equivalent is championed by Roscoe Pound as a difference between the law in the book and law in action, and by Eugen Ehrlich as a difference between norms of decision and norms of conduct (living law).

33 Some of the more famous accounts of courts and sentencing include Church, Examining Local Legal Culture, American Bar Foundation Research Journal (1985), Eisenstein and Jacob, Felony Justice (Little Brown 1977), Feeley, The Process Is the Punishment (Russel Sage Foundation 1979), Nelken 1983, Rock, The Social World of an English Crown Court. Witness and Professionals in the Crown Court Centre at Wood Green (Clarendon Press 1993), Ulmer, Social Worlds of Sentencing. Court Communities under Sentencing Guidelines (State University of New York 1997). See also the Scandinavian examples: Holmberg 1999 and 2003, Johansen 2012, Kruize, Beviskrav, ressourcer og opportunitet (Djøfs Forlag 2004), Mathiesen, Skjellig grunn til mistanke? (Pax Forlag 1989), Wandall 2009. 
departments - like earlier in the twentieth century - govern decisions about sanctioning that could otherwise have been handled by the courts. For example, community service in Sweden and electronic monitoring in Denmark. And perhaps most importantly, some cases are referred to alternative and semi-legal institutions, most significantly institutions for alternative dispute resolution. The current use of statistical causal models of sentencing shows little appreciation of these shifts in organisational frameworks and the changes in social practice that follow. Not only do we know too little about the institutional framework within which courts practice - we know even less about the framework in which sentencing is carried out in the many other places where it actually does take place.

Second, we know from many empirical studies that sentencing varies between courts and that it varies between judges. ${ }^{34}$ Nevertheless, the statistical causal model assumes uniformity in sentencing practices between courts and judges. Furthermore, we know that sentencing actually reflects social norms in daily practices of courts, and yet these are never accounted for in any of the sources of typical statistical casual models. Instead, sources of variables are often guided by the practical availability of data and the modelling guided by the statistical need to reduce the number of variables and categories to increase the overall explanatory power of the statistical model. The result is a close connection between the formal organisation of sentencing and the choice and construction of variables in the model. For example, there is a rough variable for offence category corresponding to the formal category of offence severity; there are rough variables for age and prior crime, corresponding to the equivalent formal categories, and there may be a variable of confession, corresponding to the defendant's confession to the crime, as described in the final judgment. But if this is the original full confession - which it rarely is - is not considered in the model.

So, while it must be recognised that more and more sentencing law relates to empirically based policy work and more and more statistical studies are made of sentencing, it can be argued that the same empirical descriptions remain aligned with the existing formal legal framework of sentencing decision-making. The statistical causal models may be very useful for organisational planning and for alignment with existing legal frameworks, but the power of this statistical causal model to produce empirically reliable descriptions, and to confront and challenge formal assumptions of sentencing decision-making, lacks.

\section{Conclusion}

The still most widely used model to describe actual sentencing decision-making is that of a statistical causal model. The argument advanced in this article is that this model, its design and construction of variables, needs a stronger empirical foundation. Furthermore, the article argues for a more balanced use of other and different social scientific 
methodologies to describe sentencing decision-making and the role of legal guidance in sentencing.

The statistical causal model needs to loosen its close ties with the formal construction of sentencing and instead look for a more empirically based design of its choice and construction of variables. Furthermore, descriptions of sentencing decision-making needs to be more open to the procedural aspects of how facts and law are constructed in the decision-making and should invite for a better understanding of the construction of meanings that takes place and that provide a significant framework for sentencing decision-making. The statistical causal model should come to terms with its inability to confront the legality of sentencing from a legal point of view and instead invite different models to provide a better grasp of the more complex relationship between empirical social scientific views of sentencing and a legal one. The increasing complex landscape of legal rules and regulatory standards of sentencing makes this all the more important. Moreover, the statistical causal model should reflect key institutional changes in the organisational framework of sentencing.

The statistical causal model has earlier provided a key platform for challenging how law described sentencing decision-making. The model continues to offer useful descriptions and analysis of a variety of perspectives of sentencing. Nevertheless, there are important aspects of sentencing that we cannot observe with the current widespread use of statistical causal modelling. A widening in methodology and in conceptualisation of sentencing decision-making would be a welcome development. 